TINTERNATIONAL JOURNAL OF

\title{
The Responsibility Principles in The Framework of Good Corporate Governance of The Social Welfare Institution in The Special Region of Yogyakarta
}

\author{
"Sugiyanto, ${ }^{* *}$ Heru Kurnianto Tjahjono, ${ }^{* *}$ Arief Hartono, ${ }^{* * *}$ Lathiful Khuluq \\ * Sekolah Tinggi Pembangunan Masyarakat Desa "APMD” Yogyakarta, Jl. Timoho No.317, \\ Yogyakarta, Daerah Istimewa Yogyakarta 55225, Indonesia \\ * * Dept. of Management Universitas Muhammadiyah Yogyakarta, Jl. Brawijaya, Bantul, \\ Daerah Istimewa Yogyakarta 55183, Indonesia \\ ***Universitas Islam Negeri Sunan Kalijaga Yogyakarta, Jl. Laksda Adisucipto, Kabupaten \\ Sleman, Daerah Istimewa Yogyakarta 55281, Indonesia \\ Corresponding author: \\ probosugiyanto@gmail.com
}

\section{ABSTRACT}

This research of responsibility in the framework of good corporate governance aims to know the responsibility principles in the framework of good corporate governance and governance model of social welfare institution (LKS) in the Special Region of Yogyakarta (DIY). This type of study is case study. The type of research conducted is descriptive qualitative, that is the researchers give an idea about the responsibility principles in the framework of good corporate governance of social welfare institution in DIY. The result of the research shows that there are five responsibility principles which happened to social welfare institution in DIY and there are five governance models of social welfare institution in DIY. Although the study was conducted for 8 years, this study still has weaknesses. It is advisable for further research to analyze the correlation between indicators of good corporate governance. The implications of the research are used as a reflection for policy makers, managers of LKS and donors.

Keywords:

Responsibility Principles, Good Corporate Governance, Social Welfare Institution. 


\section{INTRODUCTION}

Cadbury (1992) defines corporate governance as the balance of obligations between economic and social objectives and the goals of the individual and community goals, so that the management of all resources should consider the interests of individuals, organizations and communities that emphasize accountability.

The position of social welfare institution (LKS) in Indonesia is legally governed by the Ministry of Law and Human Rights of the Republic of Indonesia, and operationally LKS is governed by the Ministry of Social Affairs. This research was conducted in the year 2011-201\%. Until this research finished, Ministry of Social Affairs has not set good corporate governance of LKS. To deepen the principle of responsibility of good corporate governance of LKS, the researcher adopts the Decree of the Minister of BUIMN (State-owned Enterprises) No. Kep-117/ M-MBU/2002 on the application of Good Corporate Governance (GCG) on BUMN.

Corporate Governance is a structural procedure used by organ of organizations to improve the business success and corporate accountability in order to realize shareholder value over the long term by considering the interests of other stakeholders, based on laws and ethical values. The focus of business success is by considering accountability that is grounded in laws and ethical values without leaving out stakeholders who, with the long-term goal of realizing and improving the moral value of stakeholders to avoid moral hazard.

LKS is a social organization as written in Act No. 11 of 2009 on social welfare. Social Organization as referred to in the Act No. 11 of 2009 contains a specific meaning on social welfare so it is a technical term. That meaning is different from the meaning of "social organization" in a general sense, as used in sociology and other disciplines.

Why does the researcher choose the location in Special Region of Yogyakarta (DIY)? It is because DIY has 366 LKSs (Based on Social Service of DIY, 2015), LKS in DIY as a LKS barometer nationally, LKS in DIY from 2010-2017 always achieve award from the government as nationally achieving LKS, more than $25 \%$ of LKS in DIY were established before Indonesian Independence of 1945 and the indicator of inequality or Gini ratio of Yogyakarta is $4.2 \%$ and the national is $3.94 \%$. The National Standards of Childcare (SNPA) monitoring team finds data about LKS DIY that the management tends to be traditional and enclosed: (a) the human resources are not professional yet and dominated by more volunteers than LKS employees, (b) double positions: there are managements holding concurrent positions, (c) nepotism: the founder forcing its family members and public officials and friends to be included in the structure organization of LKS.

\section{THFORITICAL RFVIFW}

Pierre and Peters (2000) affirm that responsibility requires that managers be held accountable for all actions in managing the organization to stakeholders. There are two groups of stakeholders in the LKS, namely internal stakeholders and external stakeholders.

The grand theory of LKS is the organization. Taylor (1967) argues that an organization is a pattern of relationships with people under the direction of superiors to pursue a common goal, and Voos (1976) states that an organization is the social entity consciously coordinated with a relatively identifiable boundary, and work on a 
relative foundation on an ongoing basis to achieve common goals.

In Indonesia, nonprofit organizations consisting of LKSs, Social Organizations, NGOs, and LSMs (Civil Society Organization) under the protection of legal social agencies and formal foundations and its main function organized social welfare services that aim to solve the problem or meet the needs of the community. The statement is according to the results of study of Zulkhibri (2014). In this case, LKS plays role as mediator between the government and the public interests, especially people with social and community problems (PMKS) and other relevant stakeholder interests.

By adopting Chonyngton's (1910) opinion, LKS as a formal organization has the elements of: founder, builder, supervisor, manager, administrator, shareholder (philanthropy market), and client, then the working standard of LKS is not on efficiency, but rather on the effectiveness which relies on the social worker profession, social welfare workers and social volunteers. Farahmand (2011) emphasizes that these three human resources is not a hardware technology, but human ware. The obtained advantage itself is not in the form of material and not shared to stakeholders but advantages in the form of "trust" and is developed for the improvement and expansion of services to clients.

Financial Accounting Standards Board (FASB 1980) explains that there are two types of donor in nonprofit organizations, namely institutions and individuals. This explanation shows that one of the functions of nonprofit organization is to collect donors from the public and distributes to the client, then the public is eligible to know the governance specifically the responsibility and transparency in managing the donor.

\section{The History of Good Corporate Governance}

The term corporate governance is the first coined in the United States of America in 1970s. According to Cadbury (1992), corporate governance structure is a corporate influenced by culture and applicable law system so that the application on every company and countries are different (Antonella, 2001). In that case, Antonius and Subarto (2004) argue that corporate governance is defined as a matter relating to effective decision making and originating from the culture of the company, ethics, system, value, business process, policy and organizational structure aimed at encouraging the growth of the company's performance, resources management and efficient and effective risk, as well as corporate responsibility to shareholders and other stakeholders.

Government Regulation No. 101 of 2000 formulates good governance as "government who develops and applies the principles of professionalism, accountability, transparency, excellent service, democracy, efficiency, effectiveness, law supremacy, and acceptable to all communities". Corporate governance thus would restrict and regulate personal behavior in a system so that the culture of greediness depicting the battle of personal freedom and collective responsibility do not happen, because in any organization conflict of personal interests and common interests will always appear and precede each other. Consequently, there is hidden information between owner and agent (Berle and Mans, 1932).

Organization management is a very important subject, initially applied to a developing company in government management and 
then applies in all organizations, including non-profit. Therefore, nonprofit organizations are also demanded to become a professional organization to apply the principles of good corporate governance (Sektiono, D., 2016) given that in the nonprofit organization may arise a phenomenon, so that it strengthen the demands of the implementation of accountability by the organization as a whole. The demands are linked to the need for transparency and the provision of information in the effort to fulfill the rights of the public.

Alinjoyo and Zaini (2004) formulate good governance dimensions consisting of transparency, accountability, responsibility, independence and fairness (appropriateness and equality). This dimension is illustrated in the form of equity and equality in fulfilling the rights of shareholders and stakeholders based on the valid legislation; and such matters may also be accepted or applied to the LKS management. This situation is also in accordance with the stakeholder theory proposed by Mason and Mahoney (2008); Charron (2007); and Kooskora (2008). A good and ideal organization, in the implementation of an activity, certainly uses the principles of the good governance. These principles are used to keep the organization's actions in line with the objectives and actions taken not to undermine the member of the organization it serves.

\section{Good Corporate Governance of LKS}

Corporate governance of social welfare institution is the whole effort to maintain balance, sincerity, honesty, responsibility, and respect of all stakeholder done by building a value system to create justice through formal and informal rules and capital of the willingness of philanthropy markets as moral values for the best interests of the beneficiaries in a kaaffah (totally) manner (Sugiyanto 2018).

Nationally, the supreme of legal umbrella governing the LKS in Indonesia up until now is Law No. 11 of 2009 on Social Welfare. However, it still has weakness. So the government is trying to complete to strengthen the law with: 1) Regulation of the Minister of Social Affairs No. 184 of 2011 on Social Welfare Institutions (LKS), 2) Regulation of the Minister of Social Affairs No. 17 of 2012 on the Accreditation of Social Welfare Institutions, 3) Government Regulation No. 39 of 2012 on the Implementation of Social Welfare; and 4) Regulation of the Minister of Social Affairs No. 22 of 2016 on the National Standard of Social Welfare Institutions. Of the five such regulations, none has been set on the LKS organ of organization that focus on the governance of LKS, as an example, protection for LKS with no legal status, and typology devised not the one to manage the governance, but rather on the typology to fulfil the physical and nonphysical requirements on the existence of LKS. So that until now, it still have weakness since there is no rule about the governance (LKS government). Such situations and conditions are assumed to be intentionally given by the government fully to the public, considering the contents of Law No. 11 of 2009 on Social Welfare and other associated regulations was not implied. Based on this, it should be implied in the $\mathrm{AD} / \mathrm{ART}$ (rules of association and internal bylaws) of every LKS regarding the limits of the founder's powers, the relationship of the founder to the manager, the manager relationship mechanism to the beneficiary, the relationship of the founder to the beneficiary, and other matters required by the LKS. 
On the mechanism of implementation of the highest authority held by the founder, LKS execution model is implemented by the board that acts as the holder of power in operation. It is necessary mechanism of accountability of the board to the holder of the highest power. On the mechanism of accountability, the organ of organization ranging from the founder of the organization, superintendents, supervisors, managers, employees, professional and clients up to position, as well as their respective LKS authorities which is estimated to be very diverse in terms of forms and systems. In addition, it is important to explain about authority and power. It is because power and authority owned by the organ of LKS is a material to measure the performance of LKS, and finally be formulated to determine the correlation whether the LKS is health or not.

Based on the above explanation about the legal umbrella of LKS that has not set the governance of the LKS, based on the empirical study, the researcher found that the actor of LKS in the practice of governance in his organization borrow the legal umbrella of the Law of Republic of Indonesia Number 28 of 2004 about Foundation. The policy of the actor of LKS in using legal umbrella of the law on foundation is legalized by the government. In this case all of the acts of the establishment of LKS made and approved by the authorities in the form of foundations and/or social agencies.

Thus the legal umbrellas of LKS until now become double, between the Law of Republic of Indonesia Number 11 of 2009 about Social Welfare and the Law of Republic of Indonesia Number 28 of 2004 about Foundation. With this double legal umbrellas and still equipped with other legal rules that accompany, it is alleged that the governance practice in each LKS will experience differences and uniqueness. The differences and uniqueness of the management of each LKS is positively suspected to be examined for deeper study in order to develop the science in the field of non-profit organization and practically applied by the LKS actor in running the organization's wheel.

This research traces through key actors of LKS with the guidance of the Minister of Social Affair of RI Regulation No. 2Z of 2016 on the National Standard of LKS or any other factors that construct a good LKS. Based on the description above, the key actors of governance of nonprofit organization of LKS consists of founder, supervisors, superintendents, administrator and managers of the foundation, as well as external parties consisting of the government cq. Social Services, the Coordinating Board of Social Welfare Activities (BK3S), Social Welfare Activities Agency (LKKS) and donors. While for the highest forum in the LKS, there are two types, the first relates to the Management of LKS, namely at the annual plenary meeting (RPT); and second, related with client service which is in the case conference.

The core of the concept of good governance is the mechanism of inter-group relations and power structures in the process of making policy. The group in this case is the management group and the agent group. The central guidelines for the acting of managers and administrator are the value of the agreement set forth in the organization's rules (AD) and internal bylaws (ART) approved by the notary. There are six possible interactions and relationships that occur in LKS, among others: 
1. Manager (Pl) as the main actors with high relation (Rt) to stakeholders (S).

2. Manager (Pl) as the main actors with low relation (Rr) to stakeholders (S)

3. Administrator $(\mathrm{Pr})$ as the main actor with high relation (Rt) to stakeholder (S)

4. Administrator $(\mathrm{Pr})$ as the main actor with low relation (Rr) to stakeholder (S)

5. Managers (Pl) and Administrator (Pr) as the main actors with high relation (Rt) to stakeholder (S)

6. Managers (Pl) and Administrator (Pr) as the main actors with low relation (Rr) to stakeholder (S)

To know the practice of responsibilities of LKS good corporate governance, guidelines are then formulated as follows:

1. Excellent Responsibility (SB) is evidenced by the interactions and "over" relations of the values in $\mathrm{AD} /$ ART and other legislation.

2. Good Responsibility (B) is evidenced by interactions and relations which are in accordance with the values in AD/ART and other legislation.

3. Quite good Responsibility (CB) is evidenced by interactions and relations which are not in accordance with the values in the AD-ART and other regulations that legitimized.

4. Unsatisfactory Responsibility (KB) is evidenced by the interaction and deviant relation of values in the $\mathrm{AD} /$ ART and other legislation.

\section{MFTHODS}

This study of the responsibility principle within the framework of good corporate governance of LKS in DIY is conducted through literature study and focus group discussion of supra group of LKS followed by field test through case study. Literature study is conducted through international journals such as the Journal of Healthcare Management, VOLUNTAS: International Journal of Voluntary and Nonprofit Organizations., International Journal of Law and Management, Journal of Knowledge Management University of Alabama, USA, International Journal of Social welfare, etc.

Furthermore, the discussion involves 8 personnel as a team in Social Department of DIY, the profession of the team member consists of researcher in management and social field, NGO practitioner, Social Department, Social Welfare Research Center of Ministry of Social Affairs of RI Region III, and Academia of Social Welfare. Discussion is about the responsibility of good corporate governance at social welfare institution in DIY area.

Action research is done through analysis of LKS census results in 2015, accreditation forms of LKS and technical guidance activities held by Social Department and various training of capacity building of LKS held by BK3S DIY.

\section{RESULTS AND DISCUSSION}

The functions LKS are to protect, preserve and improve the social welfare of individuals, groups and communities through understanding, formation or attribute changing. The characteristic of LKS is charity-based, employing social workers, social volunteers and social welfare workers. The resources are centered on philanthropist market that does not expect for profit. The result of organization production is in the form of services in the form of "moral values", and the main resource of a non-profit organization is the 
human being as the most valuable asset because non-profit organization working principle is "off-by-to man".

\section{The Bibliography of LKS in DIY}

The results of the study of Sugiyanto, Tjahjono, HK, Hartono, A, and Khuluq, L. (2017) shows that the establishment of LKS in DIY is bottom up in nature, which means that LKS is dominated by individuals and families with the spirit of philanthropy and charity. This condition is caused by the fact that many people in Yogyakarta area are in the case of: poor, displaced, disabled, socially or behaviorally disabled, disaster victims, violence victims, exploited, and discriminated (Sukaryadi, 2014). The impact of the condition is that the governance of LKS be varied according to the capacity of family resources, but also did not rule out to produce a variety of issues, both issues of LKS internal and LKS external problem. Of the 366 LKS in DIY, it shows that the level of public participation in handling social welfare issues is quite high. The existence and role of LKS is highly relevant to the needs of society, and the data of LKS is an asset as well as an opportunity for the government to solve various existing social problems.

Based on the description above, the government through Ministry of Social Affair of Republic of Indonesia seeks to boost the quality of LKS through various regulations in order to improve the quality of LKS governance thus achieving the LKS programs activities which is targeted, integrated, and sustainable. It is because a good governance is greatly needed so that LKS can move in an ideal direction.

Speaking of funding, LKS has no independence of funds and still depends on the help of philanthropic markets and government's aid. Thus, the funding of LKS budgeting operations relies on donations. However, the presence of a family-based LKS management and limited human resources causes external parties to have difficulties in carrying out supervision. Such a situation worthy of suspicion of fraud, nontransparent, built accountability system which is prone to conflict, and moral hazard which harms various parties because their rights are not met properly. At last, public confidence on LKS is decreased.

On that basis, whether the various elements are organized in LKS or individually, they desire to help the government in accordance with the ability and knowledge of each. In this regard, the owners of LKS tend to assume that the LKS is universal so it is less understood that the presence of LKS are governed by the countries; for example in terms of the license, standardization of facilities, standardization of Human Resources, the grouping of service targets, as well as the accreditation of institutions and awards through outstanding LKS election activities.

\section{IKS Governance IModel}

Of the 366 LKS after investigation, there are five governance models, namely: 1. There are $31 \%$ of LKS with democratic governance model. This model is found on the central LKS and LKS that are universally based. Central LKS is an LKS that intentionally not opening any branch, and if open, all of the concepts, rules and policies exist in central LKS can be implemented in its branch. For universal LKS which is included in governance bureaucracy category characterized by LKSs whose management is well established, its professional human resources and stakeholders function optimally. 2. There are $9 \%$ of LKS with authoritarian 
governance model. This model is found on religion-based LKS, especially based on Islamic religion and originally developed from Islamic boarding school. The staff and volunteers seem to be the objects to work and the concepts and policies are on the leaders. In an authoritarian governance, most of the managers hold dual positions. All decisions are likely to be in the top position. This top position is at the founders or organs of the foundation, 3. There are $33 \%$ of LKS with bureaucratic governance model. This model is found in LKSs which already have a strong production unit, so that the operational fund for client service does not depend on the donor, for example LKS Mardi Wuto, LKS Anur Serimpi and branch LKS whose existence is arranged by the central LKS such as LKS Rumah Yatim , PKPU, Santa Maria and Rumah Zakat. 4. There are $10.8 \%$ of LKS with laissez faire governance model. This model is found in LKSs whose $\mathrm{AD}$ (organization's rules) has not been strong yet and has not been formed jointly among stakeholders. AD/ART tends to be created as an administrative requirement but not yet as a foundation of work, for example LKS that combines its activities between childcare institutions with Islamic boarding house and on LKS that are still new or embryo and some LKS are experiencing problems, so its source of donor is not yet clear and have not been selected. If a problem is found in laissez faire governance model, it seems that there is a shadow state in LKS (Hayden and Court, 2004). In this governance model, the stakeholder relations and interaction seems to have no strategic program policy, so that every activity is difficult to classify in preventive, curative and rehabilitative activities, 5 . There is $16.2 \%$ of LKS pragmatic governance model. This model is found in LKS whose service type is universal. It means that this LKS has many services, so that the client is holistic, for example, one LKS serve elderly, neglected child, domestic violence, etc. Pragmatic governance model seems to always take advantage of opportunities that come from government, community or corporate donors. The pragmatic governance model tends to be weak on concepts that only emphasize practicality, rather than the benefit side, emphasizes the end result of the shared values, and less concerned on the laws governing and neglecting it continuously.

Based on the growing corporate governance theory in America and Europe, it can be known that there are three potential conflictingfactorsinnonprofitorganizations: the first is the form of the organization, the second is the size of the organization, and the third is the resources owned by the organization. When it is seen from the source, there are two kinds of conflicts in nonprofit organizations: the source is from the internal of the organization, and external of the organization.

Organizational internal conflict is a conflict between internal stakeholders due to different ownership of authority and power in decision making and the use of organization resources. There are four sources of internal conflict of nonprofit organization: 1. Fractionalization of interests. Fractionalization can be seen through several things, namely the source, motivation, and duration. The source of fractionalization can be formed due to the aspects of historical, ideological and pragmatic. 2 . The tension between layers of power within the organization. The conflict in nonprofit organizations is known only to people who have worked there. The conflict in nonprofit organizations rarely raised to the public. It is often hidden or even intentionally covered for the 
sake of the organization's image. Several internal stakeholders believe that conflict is a dishonor for the organization which carries the moral values in the form of noble values and social mission therein. To some extent this conflict is one of the important factors as an obstacle to nonprofit organizations in achieving organizational goals. If there is tension between layers of supervisors and administrators, administrators and professionals, administrators and staff, staff and professionals, a very dangerous conflict can happen. Whereas, if the conflict is approached by means of positive thinking it will beneficial to the non-profit organization, i.e. as materials and learning media to the issue of governance, as a means for improving the performance of the world of nonprofit organization, as one of the pillars of democracy and social transformation. 3. Typology of leadership. There are several models of leadership types in nonprofit organizations, namely authoritarian, democratic, pragmatic and dimensional or situational. This leader model is also not free of conflict, because it can lead to weak enforcement of rules and delay in decision making because prioritizing the process. 4. The substance of organizational motion (the number of types of services provided to clients) means that the more types of services provided to clients the higher the probability of conflict and further restricting the services so that the chances of conflict will also decrease.

External organizational conflict is the factors of pressure from external policy and external resource, mainly from the donor policy and limited resource. As an example is the donor policy: in terms of transfer of donor from foreign countries to the countries whose welfare are considered lower from Indonesia; government policies, as an example of global policy is in the form of global demand for non-profit organizations (NGO-LKS) which should be subject to the discretion of the MDGs, human rights issues, the Global Compact, ISO, and others.

Basedontheaboveexplanation, itisassumed that disharmony will arise between the actors of nonprofit organizations so that the relation between the nonprofit organization actors need to be built based on moral values, including honesty, efficiency, trust, mutual respect, and equality. Such conditions not only occur between the founders, initiators, managers, staff, and professionals, as well as market philanthropist, but the same thing can happen between internal and external stakeholders, as well as between internal stakeholders and beneficiaries so that the relationships built at the social welfare institution demonstrates an effort to maintain a balance between various stakeholders and impact on the broader public level (Palupi, M. \&e Tjahjono, HK. 2016).

Based on the above elaboration, the main corporate governance orientation is to maintain a balance between the rights of all stakeholders and establish a value system to realize the moral values between stakeholders. It is related to the reputation of moral value, because when there is an institution with good moral value attributes, the philanthropic market will be formed by itself (Fadillah, 2011). In relation to that, the system built is aimed at maintaining the interests of all committed stakeholders, develop, and integrate moral values with formal and informal regulations effectively. Both arrangements aim to avoid conflicts between stakeholders.

Based on the explanation above, it can be formulated that the definition of corporate governance based on the version of the 
social welfare institutions is "the whole effort to maintain the balance, sincerity, honesty, responsibility, and respect of an entire stakeholder carried out by building a value system to achieve justice through formal and informal regulations and the willingness of philanthropist markets as the moral value for the best interests of the beneficiaries in a kaaffah (total) way."

\section{Responsibility Forms}

Good and healthy management of an organization can be detected from the implementation of good governance principles, specifically transparency and accountability. The organization authority holder party is in the hand of BOD and the Administrators. Therefore, the managers are responsible for giving responsibility of any action in managing the organization to the stakeholders.

If we adopt the organization profit, the responsibility is meant as corporate responsibility to the shareholders and stakeholders by not putting aside either the needs of the shareholders or the community members in general. In this context, it must be stick on the applicable laws on: 1 . The stakehoders' rights., 2. Fair treatment toward all stekeholders., 3. The role of stakeholders in corporate governance. 4. Obligation on disclosure and transparency., 5. Responsibility of the directors and commissioners.

Both explicitly and implicitly, there are indications that the theory of corporate governance mentioned above tends to use approaches based on the assumption on "the suspicion toward irresponsible behaviors of an inner party" toward the needs of stakeholders (Sheffied dan White 2004). It can happen for proposed reasons are related to the separation between management and owner that it increases the issues of the agency. Efforts to handle these issues are taken through: market mechanism, social and environmental values, effective regulations and supervisions, integrity and law implementation efficiency, the ownership structure and political authority as well which are able to perform tasks effectively (La Porta et al, 1999).

The results of study, John (1977), showed that the problems of non-profit institutions ate more complex since in a business organization, the party having profits in the form of materials and money is the stakeholders, "moral" owners, and benefit recipients, which is in the form of "moral value reputation". Especially on social welfare institutions, the issues will be more complex since there are more to serve with variations of 26 people with social welfare problems (PMKS). Regarding the main activities that any situations must have one voice on goals, characters, and directions that the organization goals set to be productive and to succeed the organization are reached. It is done since the reputations are frequently changing and on the other hand, the institutions operational implementation relies on "philanthrophy market".

It is related to assumption that the position of stakeholders especially administrators (agents) is determined by the moral value as corporate culture that it should be able to become the most innovative aspiration. Similarly, it also respects both personal and general value as well as obeying value consistenly in any operational aspect. It is because the basic thing is that "value will show" both in all stakeholders areas and the benefit recipients and unlimited public as well. Based on this understanding, internal stakehoders in a non-profit organization 
have to understand the philanthrophy market and benefit recipients in the frame of one voice, one step, and one heart. Therefore, the implicit demand is that understanding, responsible, and is able to do each's main tasks and functions; if it is wrong or weak, overloaded, and over acting in conducting the main tasks and functions, it is then potential to trigger conflict of interests among internal stakeholders.

\section{The foundation of value system of corporate governance of Social Welfare Institutions (LKS)}

Most of human resources of LKS consist of volunteers. Thus, LKS tries to do efforts to protect the needs of the whole stakeholders and benefit recipients in balance with a highly strong foundation as a value system, that is moral vlue based on heart bond. However, it needs to question the sincere efforts of LKS to implement the aforementioned value system responsibly without having many requirements and tactics. It is because the value system implementation is actually a personal obligation and has a great consequence and bond the whole individuals having interaction as what it is in building the relation. If it is not implemented, seen from the moral value, it proves that the group of volunteers is not included in a group of (a) volunteer (Kusumahadi, M. 2011).

The mechanism of interaction happens in LKS has a high relevance with the moral value, especially the values related to the schemes of faith, sincerity, and authority using philanthrophy market funding using the best principles for the benefit recipients. This funding gives a full trust to the philanthrophy market or donation which never demands any claim from the benefit or share. The benefit from philanthrophy market is used by the administrators for productive activities with the final results in form of moral value reputation. Also, the share received by each stakeholder depends on the agreed sincerity contract when having a personal contract with the institutions. The sincerity contract is bound by the heart bond, not by material bond that the intention on materials is not seen or in the other word, there is none of it. The value system haing moral dimension related to the need of self-discipline as the moral concept in social welfare service as it is listed in each stakeholder's spiritual moral, such as work of charity and work of philanthrophy based on the principle of belief and volunteerism. Similar statement related to the aforementioned discussion is stated by Dani Vardiansyah (2008), Palupi, M. \& Tjahjono, H.K. (2016) that faith is an attitude shown by human when they feel that they quite understand and conclude that he/ she has found the truth. This opinion is confirmed by Schwitzgebel (2006) that trust is a psychological condition when an individual considers that a premise is correct. The recognized faith, sincerity, and trust of each stakeholders of LKS are as the proofs of obedience to the words of God in accordance with the respective religion; meanwhile the volunteerism, solidarity, partnership, accountability, professionalism, participation, openness, integrity, justice, and continuity are accumulated by the government, as it is implied in Article 2 Laws Number 11 Year 2009.

The guidelines of value system believed above can be a formidable moral fortress for human to do charity work and humanity work. If both works are not in accordance with the faith, the LKS will be abandoned; and on the contrary, if both works are believed of having the same faith, the value system will be really implemented. 
However, when the value system only ends as a discourse, especially if it only becomes a value system binding any party in an LKS or organization, then moral value system no matter how good it is will not impact human behavior individually. The implementation of value system in the daily institutional life needs some prerequirements, namely: the existence of strong motivation, moral value is built systematically based on strong foundation of faith, value system is influenced by the social and economic environment and it needs to be supported by the law system and effective supervision as well (Chapra dan Ahmed,2002).

Morality value system is related to the awareness of the obligation of sharing, and doing charity is believed as the best act. It, then, creates "a pattern of understanding of which some of our wealth is others' right" believed by individuals in accordance with their own religion. On the other side, internal aspects can be built through meaningful system that applies restriction of responsibility, working target mechanism determining rewards, appreciation, and punishment to all parties involved in the system (Syalan, 2013). The system will be effective when the doers involved have the same foundation of faith that everything becoming its responsibility which should be accounted for not only in the worldly level but also becoming ukhrowiah in the afterlife.

Eventhough the internal aspects have been conducive, it is still necessary to consider the external aspects related to social, political, and economy because it will both directly and indirectly influence the internal system condition built. If the weakness of behavior norms and norms implementation in LKS is caused by the constraints of economy, science, religious understanding, and relation, pathological bureocracy happens systematically so that it influences the welfare service decline and moral degradation. Such an environment condition needs effective mechanism of regulation and supervision to be set (Chapradan Ahmed, 2002).

\section{Stakeholders as the key role of LKS Corporation}

Important factors needed to realize mechanism of effective corporation management in social welfare institutions having units related to: managers/the Board of Director (BOD) with management, internal control, effective risk management, and high transparency level and accounting standard and audit as well. Based on Chapra and Ahmed (2002), BOD has important role in management corporation with more emphasis on moral integrity than technical ability. However, BOD must understand the risk and complexity of philanthrophy market and the efforts to improve the capacity related to the profession and the basis of charity work and humanity work

Discussing the tasks of BOD, there are some tasks such as: 1) holding meeting regularly, 2) doing effective control on service condition, service facilities, finance of LKS, 3) having effective discussion with senior management and internal audit, 4) setting regulations, monitoring the development of financial institution goal achievement.

Besides, BOD also does supervision in accordance with the main tasks and functions issued by the supervision authority and modification if necessary, and is able to explain strategic goals specifically, guides philanthrophy market, ethic code for senior management and staff working standard. The existence of BOD is determined by the ability in building 
strong internal control system, effective risk management, making all procedures and regulations as well as important rules as well especially when it is related to free management senior recruitment from nepotism and favoritism based on the measured real ability (merit system).

The task of senior management is to be responsible on the institution's daily functions so that they can operate the corporate healthily and effectively by setting the system of internal audit, control procedures, and risk management. Auditor internal system is made by the senior managers based on the adequate technical skills and competencies and they acts independently so that they are freed from any operational tasks. Internal auditors regularly report the performance of the institution to the BOD and management, and BOD must play the roles so that the internal audit is not under management pressure. If the results of internal audit show things need to be followed up by the management, BOD must urge its management to do it.

Based on the aforementioned aspect, Syaflan (2013) mentioned three minimum criteria for a good management in religious language namely siddiq, amanah, fathonah, and safe from three hypocritical traits. Based on the principles, when management starts to cheat or to deviate, they start to knit difficulties for themselves. Thus, it is necessary to do efforts to increase honesty such as discipline and trustworthiness, thrifty and careful employee and staff, effective internal control as they can suppress the seeds of cheating and encourage the growth of whistle blowers (reports on malpractice and lie).

Discipline is an obedience to respect and conduct a system requiring people to obey the decisions and instructions as well as the applicable rules. In other words, discipline is an attitude of obeying the rules and regulation set sincerely.

Not only suppressing the seeds of cheating, effective internal control can also understand the issues and weaknesses found in the institution. Then, it can urge the management to find strategies to solve problems. When it lasts, it will urge the management to set planning strategies and self-readiness as well as togetherness having more orientation on long term consideration than on short term objective for success and anticipation of problems in the future. In this term, Olsen and Eadie (1982) stated that support and commitment of important people as the decision makers are vital. One of the indicators is that strategic planning is oriented on long term consideration in which the management gives high priority for activities to increase the capacity, both for education and training and for investment to adopt technology in order to improve services for the customers so that good image of the institution will be built (Chapra\&e Ahmed, 2002).

Encouraging the build and growth of whistle blowers related to the mutual consciousness to remind each other so that the internal party does not do any efforts to do deviant action from the applicable rules because it will raise the bravery of the other internal parties to vocalize the indicators or the deviations. Thus, special policy is needed to build conducive atmosphere for the growth of whistle blowers since it can create uncomfortable situation, violence, and even causing someone losing his/ her jobs.

In LKS institution, the shareholders are the philanthrophy market donating some 
of its wealth. The donors never think about the risk if they do not expect any material benefits or withdraw the capital so that they do not have any risk and the donors do not necessarily know each other. Based on this condition, LKS as a trustworthy institution for the donors through trustworthy agents need to manage the donations. It also needs to build high transparency to the philanthrophy market, and if it is known that whistle blowers happen in LKS, the donations will be stopped. Such a condition is very risky if it is not immediately anticipated because it influences systematically when there is a massive stop due to the greater LKS fund from the philanthrophy market. However, during these years, the philanthrophy market is relatively ignored meaning that the donors have not certainly got the reports or information about the fund operational implementation.

Therefore, the quality improvement of Management Corporation in social welfare institution can be done by considering the openness aspect in the representative model of the donors in BOD. In the case of the mechanism of the donation submission and donation distribution should be transparent and will be better if every group of philanthrophy market understands and gets the information or reports of the donation flows even though some of the donors do not want to know the flow of its donation flows since they trust that LKS will distribute the donations properly (BK3S DIY, 2005).

\section{The Responsibility Obstacles}

There are six weaknesses of the implementation of good corporate governance principles in social welfare institution in DIY, those are: 1. The weak government and supra LKS in controlling the LKS., 2. The high public tolerance around the LKS., 3. The weak role of BOD in controlling the management of the organization. BOD is less active in analyzing organizational management strategies., 4. Some of the LKS feel freein managing the donors for the donors never do any audit. They believe that their donation is distributed well and properly., 5. Not transparent, inaccurate, and not punctual in presenting the reports of the development of the organization and finance by the BOD to the founders and philanthrophy market., 6. Auditor problems, many LKS have not conducted the audit on the donors, both permanent or temporary donors.

\section{Responsibility Supporter}

Corporate governance, based on John and Alan (2011) is a subject having many aspects. The main theme from corporate governance is the problem of accountability and the responsibility of mandates. Other aspects of the corporate governance such as the stakeholders' point of view or the stakeholders' demands of attention, transparency, accountability or responsibility as well as justice toward the parties beside the philanthrophy market for example, to the employees, public, volunteers, and environment. The attention on the non-profit organizational management practice has increased as a proof of anxiety toward: 1. The internal needs, the existence of the BOD and LKS Chief's awareness on the efforts of external needs fulfillment, the awareness in increasing the quality of Human Resources, the efforts in fulfilling the service standard and facilities standard. For example, there is awareness of BOD to send the employee to study or the staffs' awareness in obeying rules and fulfilling clients' rights. 2. External pressures, an ideal and healthy LKS is when none of the BOD and managers 
hides any information and the information can be accessed by any of the stakeholders by keeping considering the ethic code on own's authority. In fact, there are some LKS which have not dared to provide information transparently to the parties who need it. As a proof, there is a lot of information given which is not in accordance with the facts found in the field when the LKS is given form. Another proof is when there is a new policy to manage LKS, there are some LKS refuse or contradict it for example in socializing the national standar of children raising (SNPA) which took 2 years., 3. The country needs to manage LKS as there are pro and contra in responding the country policy given to the LKS. The pro response is when the LKS administrators actively discuss, utter the difficulties, and later find solution together. On the other hand, the contra LKS do not respond or pretend that they don't know and they even do not attend the invitation to come to the Social Department or BK3S without any confirmation. On the other hand, Social Department and BK3S invite the LKS for they are responsible as a need to manage and socialize the rules have to be done by the administrators as one of their obligations, for example LKS is obliged to make accountability reports to the government every 4 months, every 6 months, and annually.

\section{CONCLUSION AND SUGGESTION}

Non-profit organization as the form of public organization started from and returned to the public themselves is required to be able to: 1. present its financial reports transparently which can be accounted for., 2. provide service to clients openly and honestly to the stakeholders and public. Both are useful to score organizational service and ability of being a going concern and to score the ways of the managers to fulfil their responsibility and manager performance aspect. Besides, the provision of vivid and transparent financial reports facilitates the managers to make accountability reports to the users.

The forms of responsibility principle violations occurring in Social Welfare Institutions (LKS) such as the difficulties of public in accessing information on donations and client services have not fulfilled clients' rights in accordance with the Declaration of Human Rights and have not been in accordance with The Constitutions of the Republic of Indonesia 1945. The violations and crimes in LKS are those typically conducted by the BOD doers or managers that they disadvantage the LKS itself. The government and LKS association should give strict sanction to the moral hazard doers so that the LKS is deterrent. Marshall et al (1985), stated that corporate crime is any action conducted by the corporate which can be given punishment by the country whether it is included in administrartive laws, civil laws, or criminal laws.

Therefore, the transparency becomes a form of protection for the public, the donors, and the stakeholders having the rights of this protection. From the substantial side, the openness enables public to get access on important information related to the organization. Seen from juridicial side, openness is an assurance for the public to keep getting important information with sanction for obstacles or negligence done by the BOD and managers. Law implementation on any violation toward the regulations on the transparency enables the philanthrophy market or donors to be protected legally from manipulation practices in public organization. For openness acts as law issuers, public company and open company must provide information openness to the investors or 
public. In the profession ethic code, Professional Social Work must always act with professional integrity, namely: a. Be aware of and reject the influences and pressures restricting the professional freedom. b. Do not misuse professional relations for personal needs.

\section{RFFFRFNCES}

Antonella, S., (2001). Debt as a Device for Corporate Control-the Case of Countries in Transition. Journal on International Banking Law, Vol. 16 (2).Hlm 48.

Antonius, A and Subarto, Z., (2004). Komisaris Independence Pengerak Praktek GCG Di Perusahaan. Penerbit Kota Indeks Kelompok Gramedia, Jakarta.

Berle, A.A., and Means.G.C., (1932). The Modern Corporation and Private Property. Macmillan Company, New York.

Cadbury, R., (1992). Report of Committee on The Financial Aspects of Corporate Governance. Great Britain: Gee.

Chapra, M.U., \& Ahmed, H., (2002). Corporate Governance in Islamic Financial Institutions. Islamic Research and Training Institute, Islamic Development Bank, Jeddah.

Charron, D.C., (2007). Stockholder and Stakeholder: The Battle from Control of The Corporation. Cato Journal; 27,1 .

Dewan Standar Akuntansi Keuangan, (2011). Pernyataan Standar Akuntansi Keuangan Nomor.45 Pelaporan Keuangan Organisasi Nirlaba. Jakarta:IAI.

Fadilah, A., (2012). Konflik Stakeholders: Studi Lembaga Kesejahteraan Sosial Anak Di Daerah Istimewa Yogyakarta. Lembaga Pers MahasiswaYogyakarta.

Farahmand, Nasser Fegh-hi. (2011). Organizational Technology Management by Humanware as Important Technology Factor. Research on Humanities and Social Sciences www.iiste.org ISSN 2224-5766 (Paper) ISSN 2225-0484 (Online) Vol.1, No.3, 2011.

Financial Accounting Standards Board,(1980).Statements of Financial Accounting Concepts No. 4 Objectives of Financial Reporting by Nonbusiness Organization. USA:.FASB.

Hayden, G., and Court, J., (2004). Governance and Development: World Governance Survey Discussion Paper 1: United NationUniversity.

John, C., (1977). Reinenting Your Board (san Francisco: Jossey-Baa, 1977), p.18.

John, L and Alan, D., (2011). Company Law.Edisi ke 7, Oxford, University Press.

Kooskora, M., ( 2008). Corporate Governance from the stakeholder perspective, in the context of Estonian business organizations. Baltic Journal of Management. Vol. 3 No. 2, pp.193$21 \%$.

Kusumahadi, M., (2011). Posisi dan Langkah Strategis BK3S-DIY Dimasa Mendatang, Satu Nama, Yogyakarta.

La Porta, R., Lopez-de Silanes, F.,\& Shleifer, A., (1999). Corporate Ownership around the World. Journal of Finance, 54, 471-51\%. 
Marshall B. Clinard and Peter C. Yeager., (1985). Corporate Ethics And Crime The Role Of Middle Management, Sage Publications. USA.

Mason, M., \&e O’ Mahoney, J., (2008). Post-traditional Corporate Governance. The Journal of Corporate Citizenship; Autumn 2008;31.

Olsen, J. B., and Eadie, D.C., (1982), The Game Plan : Governance with Foresight. Washington: Council of Stare Planning Agencies.

Palupi, M. and Tjahjono, H.K., (2016). A model of religiousity and: The Impact on commitment and dysfunctional behavior. Proceeding of the $27^{\text {th }}$.International Business Information Management Association Conference.

Peraturan Menteri Sosial Republik Indonesia Nomor 184 Tahun 2011 tentang Lembaga Kesejahteraan Sosial.

Peraturan Menteri Sosial Republik Indonesia Nomor 22 Tahun 2016 tentang Standar Nasional Lembaga Kesejahteraan Sosial.

Peraturan Pemerintah Republik Indonesia Nomor 39 Tahun 2012 tentang Penyelenggaraan Kesejahteraan Sosial.

Pierre, J., and Peters, B.G., (2002),Governance, Politics and the State. New York: St. Martin'sPress-Reno.

Schwitzgebel, E., (2006), "Belief", di Zalta, Edward, The Stanford Encyclopedia of Philosophy, Stanford, CA: The Metaphysics Research Lab, diakses tanggal 2-11-2016.

Sektiono, D., and Nugraheni, R., (2016), Implementasi Good Governance Lembaga Swadaya Masyarakat. Studi Kasus Pada Aksi Cepat Tanggap Cabang Semarang. Universitas Diponegoro, Semarang Indonesia.

Sheffied J. and White, S., (2004), Control self-assessment as a route toorganizational excellence: AScottish Housing Association Case Study Managerial Auditting Journal: 19,4;pg.484.

Sugiyanto, (2018),Tipologi Governance Lembaga Kesejahteraan Sosial.Studi kasus di LKS Mardi Wuto dan Hamba DIY.Desertasi Fakultas Ekonomi Universitas Islam Indonesia.

Sugiyanto, Tjahjono, H.K., Hartono, A., Khuluq, L., (2017). Phenomenological Study on the Governance "Social welfare Institutions" in Special Region of Yogyakarta, Prosceding International Business Information Management Association, Madrid Spain Nopember $201 \%$.

Sukariyadi, U., (2014), Penyandang Masalah Kesejahteraan Sosial dan Potensi Sumber Kesejahteraan Sosial DIY, Dinas Sosial Daerah Iistimew Yogyakarta.

Surat Keputusan Menteri BUMN No.Kep-117/M-MBU/2002 tanggal 31 Juli 2002 tentang Penerapan Good Corporate Governance pada BUMN.

Syaflan, M., (2013), Tipologi Governance Baitul Maal Wat Tamwil (BMT) Di DIY, Desertasi Fakultas Ekonomi Universitas Islam Indonesia.

Taylor, F.W., (1967), The Principles of Scientific Management, The Narton. Library. New York.

Thomas, C., (1910), The Modern Corporation, Then Ronald Press. New York.

Laws of Republic of Indonesia Number 11 Year 2009 on Social Welfare

Laws of Republic of Indonesia Number 28 Year 2004 on Foundation

Vardiansyah, D., (2008), Filsafat Ilmu Komunikasi: Suatu Pengantar, Indeks, Jakarta.

Voss, G.L.,(1976), Seashore life of florida and the Carribbean. Banyan Books, Inc. Miami, Florida.

Zulkhibri, M., (2014), Regulation governing non-profit organizations in developing countries: A comparative analysis, International Journal of Lawa and Management, Vol. 56 Issue: 4, pp 251-273. 